\title{
Preparation, Characterization, Biological Evaluation and Assess Laser Efficacy for New Derivatives of Imidazolidin-4-one
}

\author{
Adil Hussein Dalaf ${ }^{1, *}$, Fawzi Hameed Jumaa ${ }^{2}$, Hanaa Kaain Salih ${ }^{1}$ \\ ${ }^{1}$ Department of Chemistry, College of Science, Tikrit University, Tikrit-Iraq. \\ 2 Department of Chemistry, College of Education for Women, Tikrit University, Tikrit-Iraq. \\ * Corresponding author email: adil.h.dalaf@tu.edu.iq \\ DOI: https://doi.org/10.34256/irjmt2145 \\ Received: 20-04-2021, Revised: 12-06-2021, Accepted: 20-06-2021, Published: 27-06-2021
}

Abstract: In this study, new Imidazolidin-4-one [A1-A5] compounds were prepared by the reaction of schiff base compounds with alanine in ethanol. The prepared compounds were characterized by physical properties, UV-Vis, FT-IR and $1 \mathrm{H}-\mathrm{NMR}$ spectral and C.H.N analysis. TLC checked the purity for these compounds. All compounds [A1A5] were prepared by the traditional method (reflux) and microwave technology. It was found that using the microwave method gives better results in terms of less time and, higher yield. Antibacterial behaviors were investigated against a variety of bacteria, including Escherichia coli and Klebsiella pneumonia Gram (-) ve, Staphylococcus aureus, and Staphylococcus epidermidis Gram (+) ve. The laser efficacy of the compounds [A1-A5] was evaluated after they were radiated by laser for $(10,20,30)$ seconds. As the melting point and color of the substances were determined, it was discovered that they were unaffected and did not disintegrate or polymerize. Using the Chem Draw Specialist 19.0 program, the stereoisomers of the prepared compounds [A1-A5] were examined at the lowest layer stage. Using the Chem3D 19.0 program, the heat of the formulation of the compounds [A1-A5] was also investigated.

Keywords: Imidazolidin-4-one, Biological Activity, Laser Effectiveness.

\section{Introduction}

Imidazolidin-4-one is one of the five-ring heterocyclic compounds which have a vital application in biological as well as nonlinear optical applications and that contain four nitrogen atoms and a carbon atom in addition to hydrogen atoms [1]. The simplest of them is the compound (Imidazolidin-4-one) with the formula $\mathrm{CH} 2 \mathrm{~N} 4$ [2]. These compounds are considered one of the most effective cyclic compounds because they possess four free pairs of electrons for four nitrogen atoms of the electron propellant compounds [3]. This Imidazolidin-4one is prepared by cyclic addition between Schiff base compounds and alanine [4]. Imidazolidin-4-one compounds and their derivatives possessed great importance, especially in the biological field, as the prepared compounds showed anti-bacterial, anti-fungal, and anti-viral efficacy [5]. They were also used in the preparation of medicinal drugs to treat chronic diseases, as well as used as anti-hypertension, showing antibacterial and anti-fungal effectiveness, anti-cancer efficacy, and anti-spasmodic efficacy [6,7]. They play important roles in coordination chemistry, in the photographic industry, or as components of special explosives [8, 9]. As a result of their acidities, 5monosubstituted Imidazolidin-4-ones are also used as activators in oligonucleotide synthesis [10]. However, the most important use of Imidazolidin is to be found in medicinal chemistry [11]. The first compound containing an imidazolidin ring to have been prepared is thought to be 2-phenyl-2H-imidazolidin-4-one-5-carbonitrile, which was prepared and characterized in 1885 [12, 13].

\section{Experimental details}

\subsection{Material and Device's instrument:}

Both chemicals were used precisely as they were given by the producer (Alfa Aesar and Aldrich). The melting points were measured using the Electrothermal Melting Apparatus 9300 in uncorrected free capillary tubes. The reaction was tracked, and purity was tested using thin-layer chromatography (TLC). Microwave synthesis workstation MAS-II. The FT-IR spectra were captured using a Shimadzu FT-IR $8400 S$ spectrophotometer with a scale of $(400-4000) \mathrm{cm}^{-1}$. The UV-Vis spectra were calculated using a Shimadzu 800UV in the range (200-400) $\mathrm{nm}$ in ethanol. 
Chloroform- $\mathrm{d}^{6}$ as solvents were used to capture ${ }^{1} \mathrm{H}-\mathrm{NMR}$ $600 \mathrm{MHZ}$. C.H.N research was used to evaluate the spectrophotometer components' quantitative analysis. A 1-milliwatt helium-neon laser beam (visible laser) with a wavelength of $600-700$ nanometers was used to irradiate the prepared compounds.

\subsection{Prepare of Imidazolidin-4-one $\left[A_{1}-A_{5}\right]$ in the traditional methods:}

In $45 \mathrm{ml}$ of ethanol, Schiff bases prepared [14] $(0.001 \mathrm{~mol})$ are combined with $(0.002 \mathrm{~mol}, 0.18 \mathrm{gm})$ of alanine and refluxed for (3-7) hours. The residue was extracted, and acetone was used to re-crystallize it [15]. Table (1) describes the physical properties.

\subsection{Prepare of Imidazolidin-4-one $\left[A_{1}-A_{5}\right]$ in the microwave methods:}

In $15 \mathrm{ml}$ of ethanol, Schiff bases prepared [15] $(0.001 \mathrm{~mol})$ are combined with $(0.002 \mathrm{~mol}, 0.18 \mathrm{gm})$ of alanine and microwaved for (4-8) minutes (ability 600 $W)$. The residue was extracted, and acetone was used to re-crystallize it [15].

\section{Results and Discussion}

In this research, five compounds were prepared including Imidazolidin-4-one $\left[A_{1}-A_{5}\right]$ as in the scheme (1) and characterized by UV-Vis, FT-IR, 1H-NMR Spectra and C.H.N analysis.

\subsection{Characterization Of Imidazolidin-4-One Derivatives $\left[A_{1}-A_{5}\right]$}

The reaction of 2 moles of alanine with schiff bases in ethanol yielded Imidazolidin-4-one derivatives
[A $\left.A_{1}-A_{5}\right]$. UV spectra show the transions $n-\pi^{*}$ and $\pi-\pi^{*}$ which have confirmed the presences of the un-bonded pair electrons on nitrogen, oxygen atoms and aromatic system (double bond) as seen in figures (12). UV \& IR absorbance spectra are given in table (2).

The FT-IR spectrum revealed the disappearance of the band azomethine $(\mathrm{HC}=\mathrm{N})$ group, as well as the emergence of bands at (3402-3454) $\mathrm{cm}^{-1}$ due to the $(\mathrm{OH})$, and appearances of bands at (3231$3278) \mathrm{cm}^{-1}$ due to the $(\mathrm{NH})$, and appearances of bands at (3052-3091) $\mathrm{cm}^{-1}$ due to the $(\mathrm{CH})$ aromatic, as well as appearances of bands at $(2937-2991) \mathrm{cm}^{-1}$ due to the $(\mathrm{CH})$ aliphatic. Aside from the bands at $(1581-1598) \mathrm{cm}$ ${ }^{1}$ and $(1481-1506) \mathrm{cm}^{-1}$ due to the $(\mathrm{C}=\mathrm{C})$ aromatic ring, and at (1425-1442) $\mathrm{cm}-1$ for $(\mathrm{N}=\mathrm{N})$ azo group, there are other bands at (1213-1250) $\mathrm{cm}^{-1}$ due to the (C-N) group and (1067-1093) $\mathrm{cm}^{-1}$ due to the (N-N) group [16]. as seen in figures (1-3). Table (2) shows the UV and FT-IR continuum.

${ }^{1} \mathrm{H}-\mathrm{NMR}$ (400 MHz, Chloroform-d) $\delta / \mathrm{ppm}$ to the [ $\left.\mathrm{A}_{1}\right]$ Compound: $(1.22 \& 1.23)\left(\mathrm{d}, 6 \mathrm{H}, 2 \mathrm{CH}_{3}\right) ;(3.51,3.52$ \& 3.53) (t, $2 \mathrm{H}, 2 \mathrm{NH}$ Imidazolidin-4-one); (3.91-3.95) (f, $2 \mathrm{H}, 2 \mathrm{CH}$ Imidazolidin-4-one); (6.21 \& 6.22) (d, $2 \mathrm{H}, 2 \mathrm{CH}$ Imidazolidin-4-one); (6.99-7.95) (m, 22H, Aromatic benzene); 7.53 (s, Chloroform-d); 8.31 (s, 2H, 2OH). As shown in figure (4).

In addition, the ${ }^{1} \mathrm{H}-\mathrm{NMR}(400 \mathrm{MHz}$, Chloroformd) $\delta / \mathrm{ppm}$ to the $\left[\mathrm{A}_{5}\right]$ Compound: $(1.22 \& 1.23)(\mathrm{d}, 6 \mathrm{H}$, $\left.2 \mathrm{CH}_{3}\right) ; 2.30\left(\mathrm{~s}, 6 \mathrm{H}, 2 \mathrm{CH}_{3}\right) ;(3.51,3.52 \& 3.53)(\mathrm{t}, 2 \mathrm{H}$, $2 \mathrm{NH}$ Imidazolidin-4-one); (3.91-3.95) (f, $2 \mathrm{H}, 2 \mathrm{CH}$ Imidazolidin-4-one); 6.09 (s, $2 \mathrm{H}, 2 \mathrm{CH}=\mathrm{C}$ isoxazole); (6.25 \& 6.27) (d, 2H, 2CH Imidazolidin-4-one); (6.997.95) ( $\mathrm{m}, 22 \mathrm{H}$, Aromatic benzene); 7.46 (s, Chloroformd); $8.31(\mathrm{~s}, 2 \mathrm{H}, 2 \mathrm{OH})[17]$. As shown in figure (5).

Table 1. Physical properties and elemental analysis of prepared compounds $\left[A_{1}-A_{5}\right]$

\begin{tabular}{|c|c|c|c|c|c|c|c|c|c|}
\hline \multirow{2}{*}{$\begin{array}{l}\text { Comp. } \\
\text { No. }\end{array}$} & \multirow[t]{2}{*}{$\mathrm{Ar}$} & \multirow{2}{*}{$\begin{array}{l}\text { Molecular } \\
\text { Formula } \\
\text { M. Wt. }\end{array}$} & \multirow[t]{2}{*}{ Color } & \multirow{2}{*}{$\begin{array}{l}\text { M.P } \\
\left(C^{0}\right)\end{array}$} & \multirow{2}{*}{$\begin{array}{l}\text { Ref. } \\
\text { (hr.) }\end{array}$} & \multirow{2}{*}{$\begin{array}{c}\text { R.f. } \\
\text { MeOH }\end{array}$} & \multicolumn{3}{|c|}{ found / (calc.) \% } \\
\hline & & & & & & & $\mathrm{C} \%$ & $\mathrm{H} \%$ & N\% \\
\hline$A_{1}$ & & $\begin{array}{c}\mathrm{C}_{44} \mathrm{H}_{38} \mathrm{~N}_{8} \mathrm{O}_{4} \\
742.84\end{array}$ & Green & $250-252$ & 3 & 6 & $\begin{array}{l}71.31 \\
(71.14)\end{array}$ & $\begin{array}{l}5.09 \\
5.16)\end{array}$ & $\begin{array}{l}14.97 \\
15.08)\end{array}$ \\
\hline$A_{2}$ & & $\begin{array}{c}\mathrm{C}_{44} \mathrm{H}_{36} \mathrm{~N}_{10} \mathrm{O}_{8} \\
832.83\end{array}$ & Red & $210-212$ & 3 & .82 & $\begin{array}{l}63.37 \\
(63.46)\end{array}$ & $\begin{array}{l}4.39 \\
(4.36)\end{array}$ & $\begin{array}{l}16.75 \\
(16.82)\end{array}$ \\
\hline$A_{3}$ & & $\begin{array}{c}\mathrm{C}_{40} \mathrm{H}_{34} \mathrm{~N}_{12} \mathrm{O}_{4} \\
746.79\end{array}$ & Orange & $291-292$ & 6 & .77 & $\begin{array}{l}64.50 \\
(64.33)\end{array}$ & $\begin{array}{l}.51 \\
(4.59)\end{array}$ & $\begin{array}{l}22.60 \\
(22.51)\end{array}$ \\
\hline $\mathrm{A}_{4}$ & & $\begin{array}{c}\mathrm{C}_{44} \mathrm{H}_{38} \mathrm{~N}_{8} \mathrm{O}_{6} \\
774.84\end{array}$ & Yellow & $270-271$ & 7 & 0.40 & $\begin{array}{l}68.10 \\
(68.21)\end{array}$ & $\begin{array}{l}5.02 \\
(4.94)\end{array}$ & $\begin{array}{l}14.53 \\
(14.46)\end{array}$ \\
\hline$A_{5}$ & & $\begin{array}{c}\mathrm{C}_{52} \mathrm{H}_{46} \mathrm{~N}_{12} \mathrm{O}_{10} \mathrm{~S}_{2} \\
1063.13\end{array}$ & Gray & $258-260$ & 3 & 0.9 & $\begin{array}{l}58.59 \\
(58.75)\end{array}$ & $\begin{array}{l}4.35 \\
(4.36)\end{array}$ & $\begin{array}{l}15.88 \\
(15.81)\end{array}$ \\
\hline
\end{tabular}




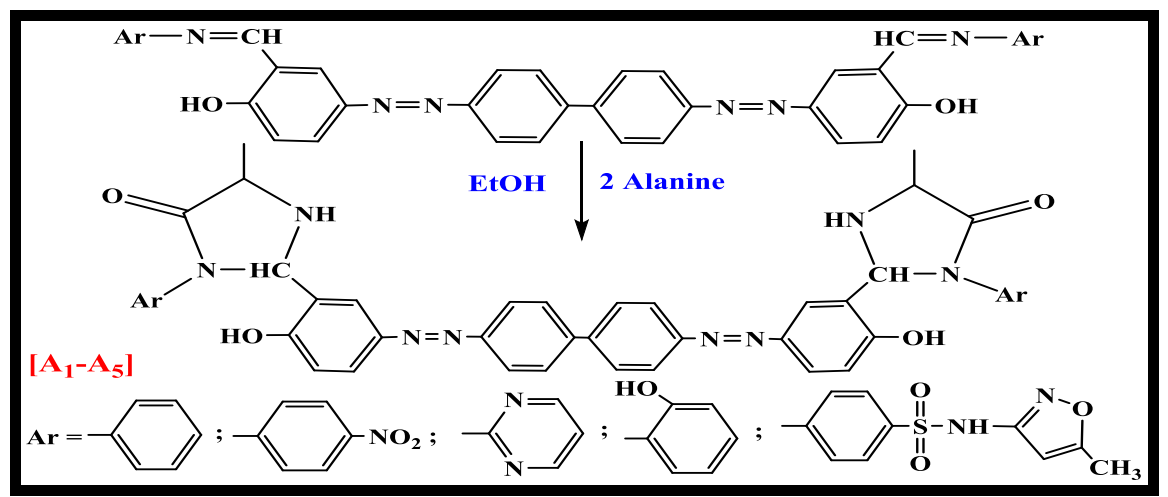

Scheme 1. Route of prepared compounds $\left[A_{1}-A_{5}\right]$

Table 2. FT-IR and UV/Vis data of prepared compounds [A1-A5]

\begin{tabular}{|c|c|c|c|c|c|c|c|c|}
\hline \multirow[b]{2}{*}{$\begin{array}{l}\text { Comp. } \\
\text { No. }\end{array}$} & \multirow[b]{2}{*}{ Ar } & \multirow[b]{2}{*}{$\begin{array}{l}\max _{1} \\
\mathrm{Amax}_{2} \\
\mathrm{MeOH}\end{array}$} & \multicolumn{6}{|c|}{ IR (KBr) cm-1 } \\
\hline & & & $\begin{array}{l}(\mathrm{O}-\mathrm{H}) \\
v(\mathrm{~N}-\mathrm{H})\end{array}$ & $\begin{array}{l}v(\mathrm{C}-\mathrm{H}) \\
\text { Arom. } \\
\text { Aliph. }\end{array}$ & $v(\mathrm{C}=\mathrm{O})$ & $v(\mathrm{C}=\mathrm{C})$ & $\begin{array}{l}v(\mathrm{~N}=\mathrm{N}) \\
v(\mathrm{C}-\mathrm{N})\end{array}$ & Others \\
\hline$A_{1}$ & & $\begin{array}{l}234 \\
385\end{array}$ & $\begin{array}{l}3384 \\
3232\end{array}$ & $\begin{array}{l}3078 \\
2948\end{array}$ & 1693 & $\begin{array}{l}1591 \\
1479\end{array}$ & $\begin{array}{l}1402 \\
1257\end{array}$ & $\ldots$ \\
\hline$A_{2}$ & & $\begin{array}{l}255 \\
391\end{array}$ & $\begin{array}{l}3342 \\
3190\end{array}$ & $\begin{array}{l}3077 \\
2919\end{array}$ & 1675 & $\begin{array}{l}1596 \\
1489\end{array}$ & $\begin{array}{l}1434 \\
1245\end{array}$ & $\begin{array}{l}v\left(\mathrm{NO}_{2}\right) \\
\text { asy.(1559),sym.(1382) }\end{array}$ \\
\hline $\mathrm{A}_{3}$ & & $\begin{array}{l}216 \\
340\end{array}$ & $\begin{array}{l}3409 \\
3215\end{array}$ & $\begin{array}{l}3058 \\
2952\end{array}$ & 1650 & $\begin{array}{l}1585 \\
1483\end{array}$ & $\begin{array}{l}1417 \\
1263\end{array}$ & $v(\mathrm{C}=\mathrm{N})(1687)$ \\
\hline $\mathrm{A}_{4}$ & & $\begin{array}{l}239 \\
308\end{array}$ & $\begin{array}{l}3399 \\
3265\end{array}$ & $\begin{array}{l}3074 \\
2921\end{array}$ & 1666 & $\begin{array}{l}1585 \\
1479\end{array}$ & $\begin{array}{l}1419 \\
1294\end{array}$ & $\ldots+\ldots .$. \\
\hline$A_{5}$ & & $\begin{array}{l}242 \\
377\end{array}$ & $\begin{array}{l}3423 \\
3212\end{array}$ & $\begin{array}{l}3082 \\
2981\end{array}$ & 1656 & $\begin{array}{l}1591 \\
1482\end{array}$ & $\begin{array}{l}1432 \\
1210\end{array}$ & $\begin{array}{l}v\left(\mathrm{SO}_{2}\right) \\
\text { asy.(1368),sym.(1147) }\end{array}$ \\
\hline
\end{tabular}

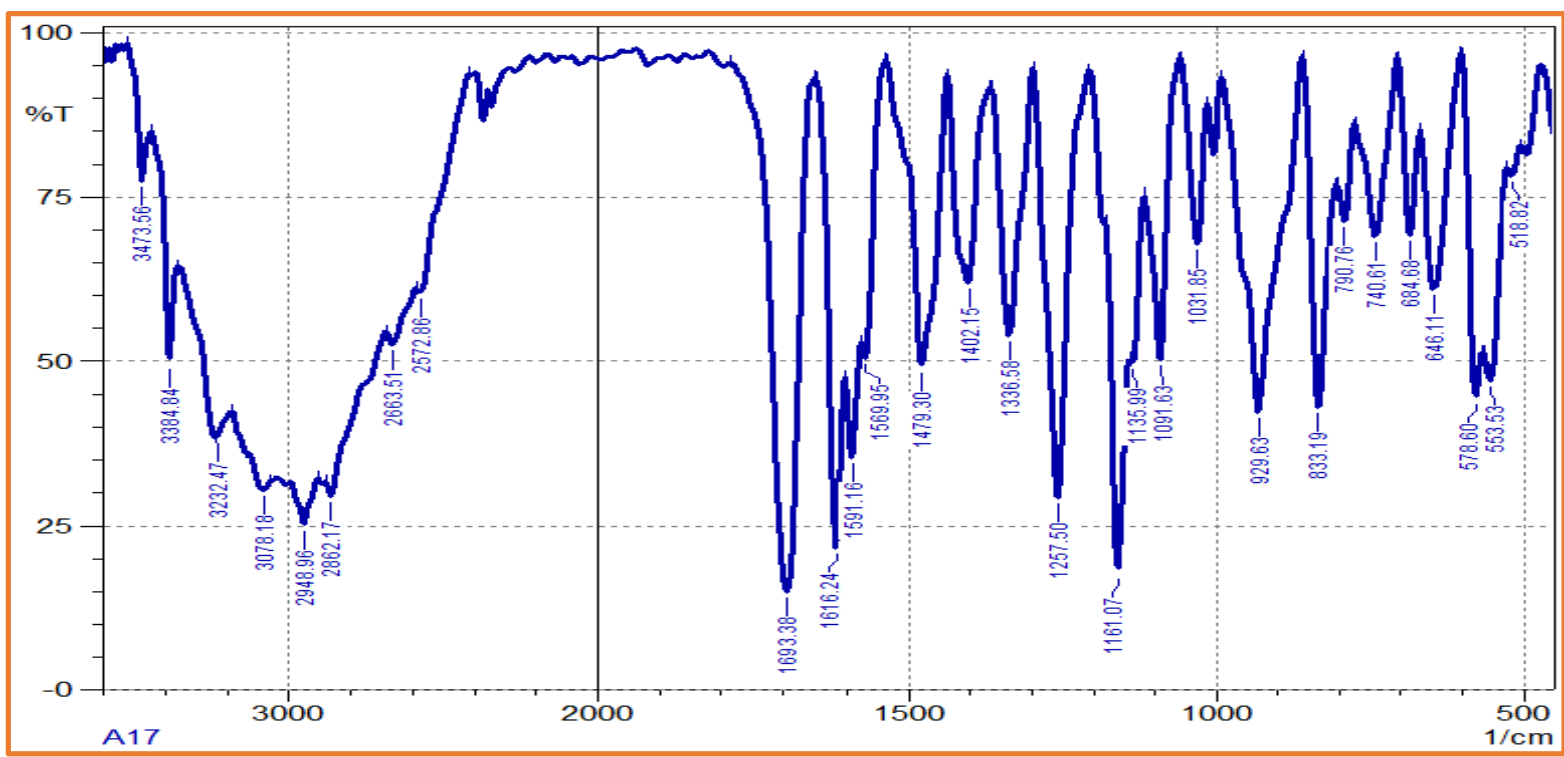

Figure 1. FT-IR spectrum of compound [A1] 


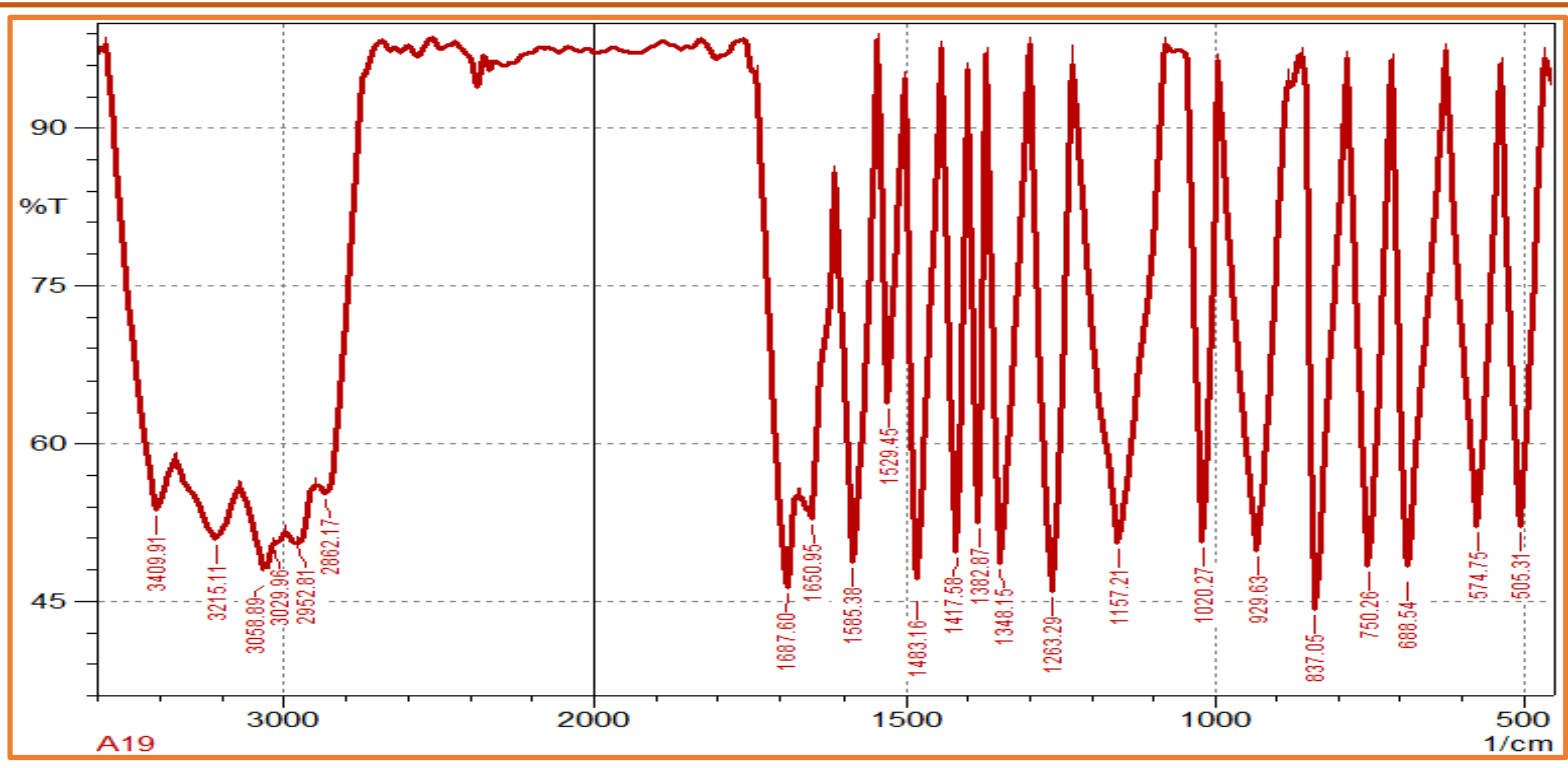

Figure 2. FT-IR spectrum of compound [A2]

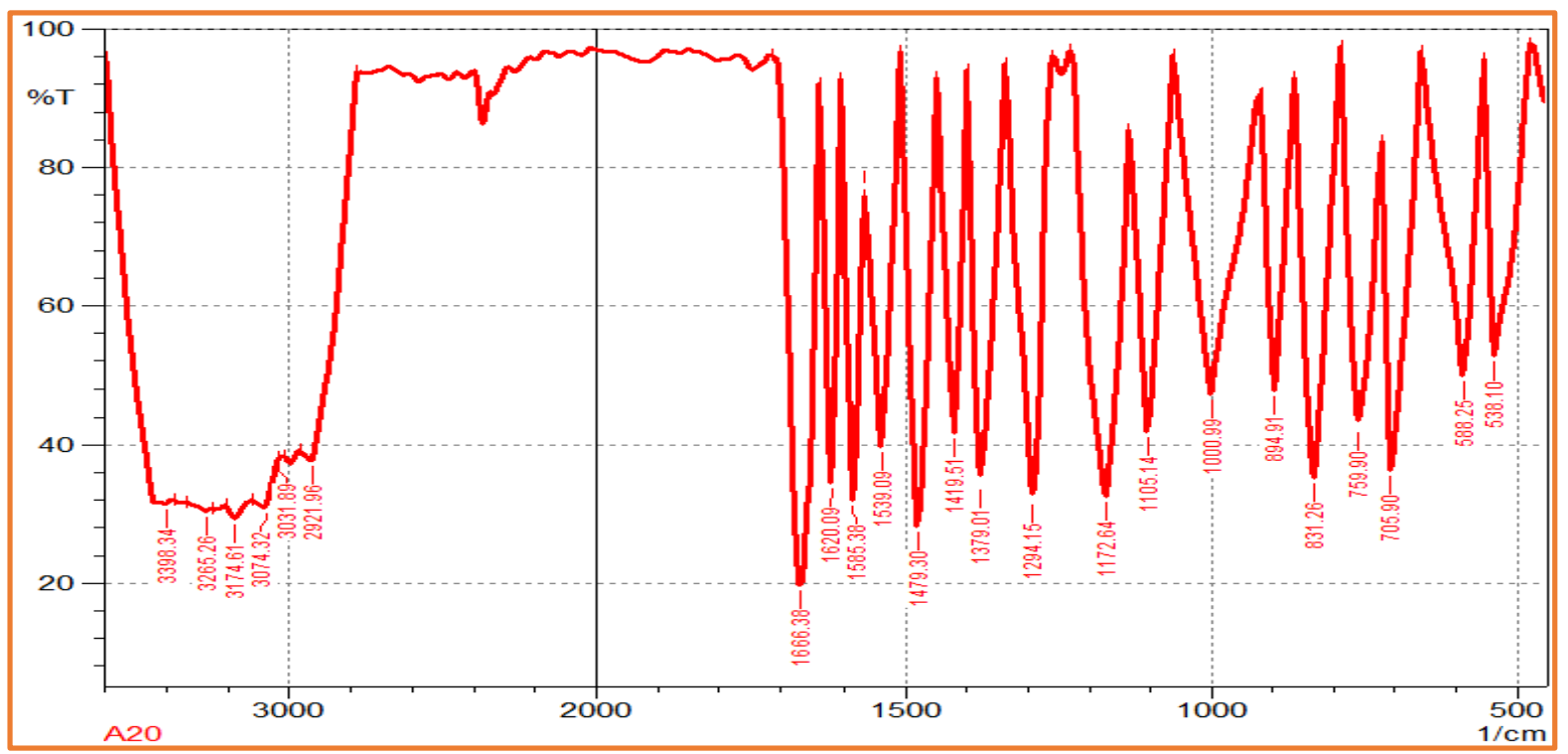

Figure 3. FT-IR spectrum of compound [A4]

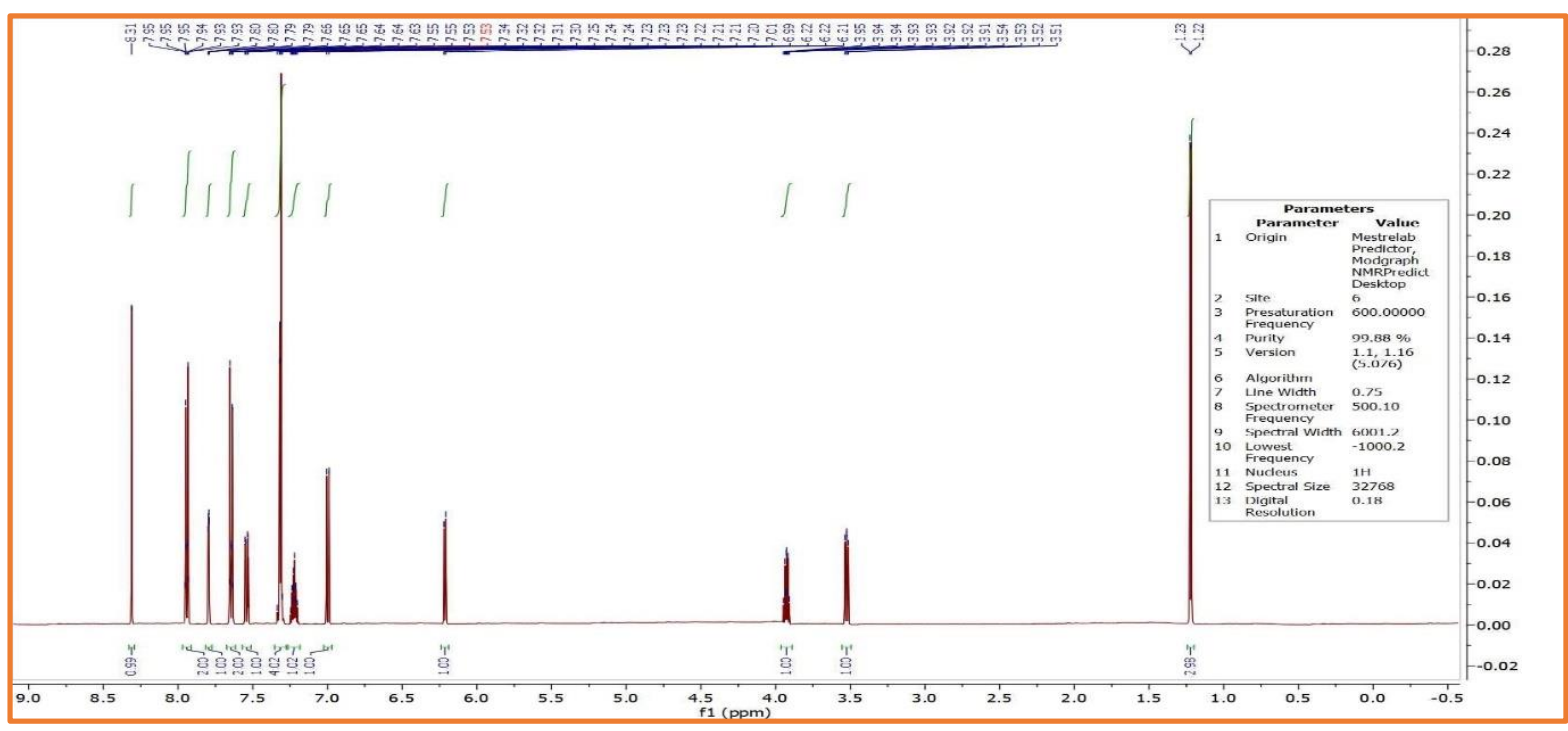

Figure 4. 1H-NMR spectrum of compound [A1] 


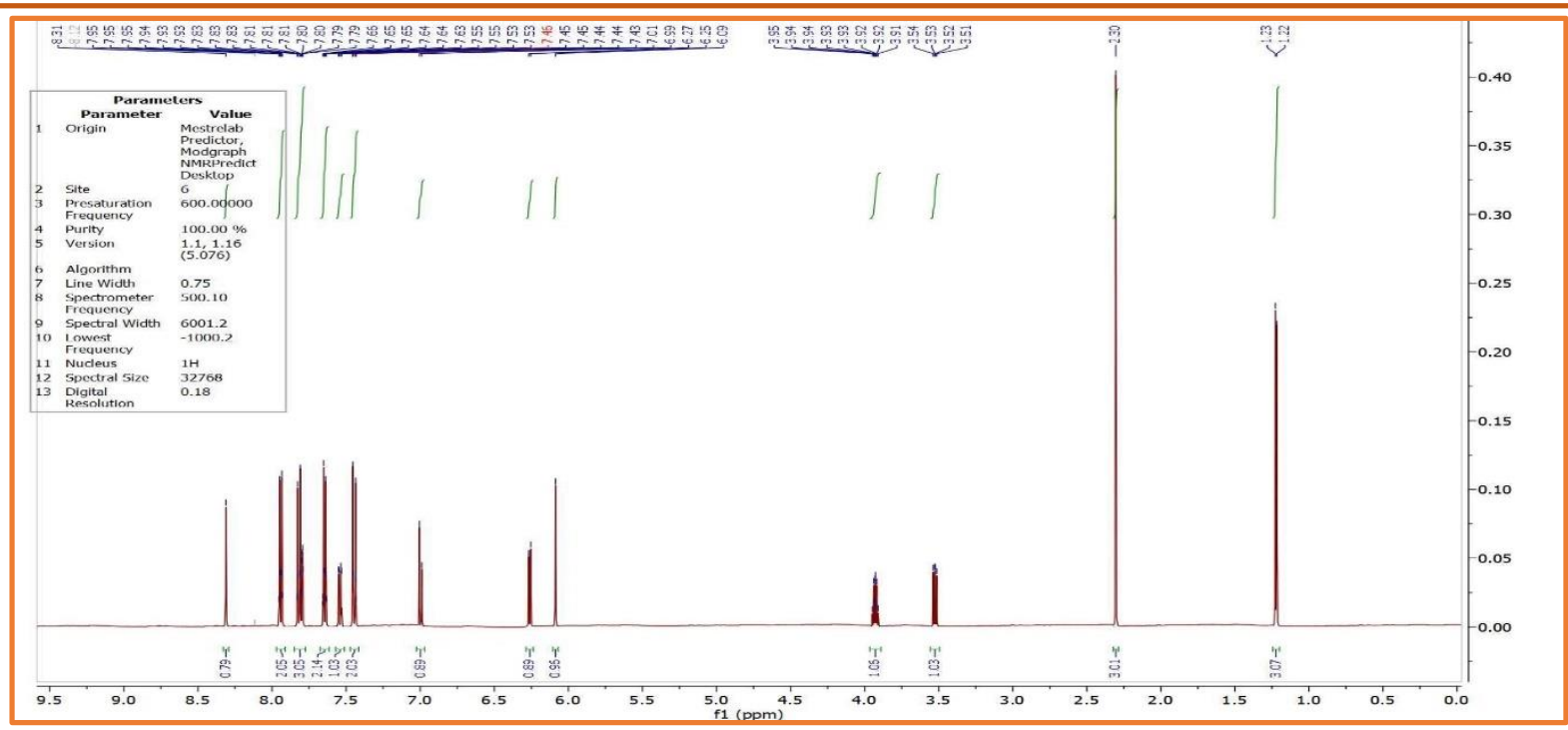

Figure 5. 1H-NMR spectrum of compound [A5]

Table 3. Solubility test for prepared compounds [A1-A5]

\begin{tabular}{|c|c|c|c|c|c|c|c|c|c|c|c|c|c|c|}
\hline Comp. No. & $\begin{array}{l}\mathbf{3} \\
\stackrel{\mathbf{D}}{\mathbf{T}} \\
\stackrel{0}{\mathbf{D}} \\
\text { 으 }\end{array}$ & $\begin{array}{l}\text { 뭄 } \\
\text { 우 }\end{array}$ & న & 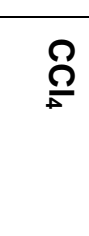 & 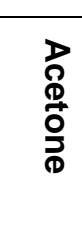 & $\frac{\text { m }}{\stackrel{\widetilde{\sigma}}{\frac{9}{9}}}$ & 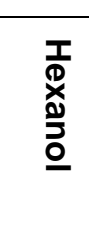 & 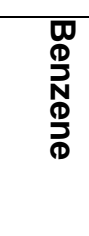 & 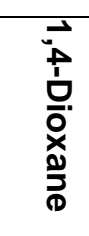 & 검 & $\begin{array}{l}\text { ס } \\
\text { फू }\end{array}$ & 号 & $\begin{array}{l}\frac{\rho}{T} \\
\frac{\rho}{\omega}\end{array}$ & 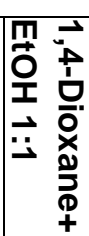 \\
\hline$A_{1}$ & + & - & - & $\div$ & - & $\div$ & $\div$ & - & - & + & + & + & + & + \\
\hline$A_{2}$ & + & - & - & $\div$ & - & $\div$ & $\div$ & - & - & + & + & + & + & + \\
\hline$A_{3}$ & + & - & - & $\div$ & - & $\div$ & $\div$ & - & - & + & + & + & + & + \\
\hline $\mathrm{A}_{4}$ & + & - & - & $\div$ & - & $\div$ & $\div$ & - & - & + & + & + & + & + \\
\hline$A_{5}$ & + & - & - & $\div$ & - & $\div$ & $\div$ & - & - & + & + & + & + & + \\
\hline
\end{tabular}

(+) soluble, (-) Insoluble, (†) Poorly soluble

\subsection{Solubility Test for Prepared Compounds $\left[A_{1}-A_{5}\right]$}

The prepared compounds are thermally stable at normal temperatures, as it is noticed that Imidazolidin4-one derivatives $\left[A_{1}-A_{5}\right]$ are completely dissolved in methanol, THF, DMSO, DMF, $\mathrm{CHCl}_{3}$ and mix 1,4dioxane whit $\mathrm{EtOH}$, as well as not soluble in solvents $\mathrm{EtOH}, \mathrm{H}_{2} \mathrm{O}$, acetone, benzene, 1,4-dioxane, and are poorly soluble in solvents $\mathrm{CCl}_{4}$, ether, hexanol as shown in the table (3).

\subsection{Discuss Difference Between Preparing Compounds Using Traditional Method (Reflux) And Microwave Method}

All compounds $\left[A_{1}-A_{5}\right]$ were prepared by the traditional method (reflux) and then prepared by microwave technology to compare the two methods in terms of using the solvent and, the time taken for the reaction, the percentage of the yield, the degree of melting, the color and the solubility, as it was found that using the microwave method to prepare the organic compounds gives better results where they are used. The amount of solvent is less than in the traditional method (reflux). The yield ratio is higher, the byproducts are very little or no, and the time taken for the reaction is very short compared to the time taken by the traditional method (reflux), as well as the ease of isolating the products prepared by microwave technology compared to the traditional method (reflux). As for the physical properties of the compounds prepared by the microwave method, the melting point, color and solubility are identical to the compounds prepared by the traditional method (reflux) [18], as shown in table (4). 


\subsection{Antibacterial Activity}

The antibacterial function of compounds [ $\left.A_{1}-A_{5}\right]$ was evaluated using the disk diffusion system against four bacteria: Escherichia coli and Klebsiella Pneumonia Gram (-) ve, Staphylococcus aureus, and Staphylococcus epidermidis Gram (+) ve. The disks were then immersed in DMSO and dried in an incubator before being used in bacteria cultures. The plates were incubated for two days at $37^{\circ} \mathrm{C}$. Maximum inhibition zone diameter (IZD) was observed and calculated. At three doses, ampicillin, amoxicillin, and Ciprofloxacin were used as monitoring samples. The findings revealed that certain of the compounds had antibacterial activity. Compound $\left[A_{1} \& A_{2}\right]$ showed weak and moderate activity against the bacterial species used. Compounds $\left[A_{3}, A_{4} \&\right.$ $\left.A_{5}\right]$ gave strong efficacy and high inhibition, reaching (5) $\mathrm{cm}$ at a concentration of (100) $\mathrm{mg} / \mathrm{ml}$ and reached $(4) \mathrm{cm}$ at Concentration (50) $\mathrm{mg} / \mathrm{ml}$ against all bacterial species used in the study [19-23]. Table (5), and scheme (2-5) demonstrate the effects of the inhibition zone diameter (IZD) in millimeters.

\subsection{Lasers' Impact on Prepared Compounds [A1-A5]}

A laser with a (5) milliwatt power emits laser rays in the visible spectrum with a wavelength of (600-700) $\mathrm{nm}$ in continuous waves. The laser was used to irradiate the compounds $\left[A_{1}-A_{5}\right]$ for $(10,20,30)$ seconds. The substances were discovered to be untouched. When the melting point and color were determined, they did not disintegrate or polymerize. This indicates that the substances were untouched by the laser beams. They are secure, as shown by table (6) [24].

\subsection{Influence of Stereochemistry and Heat of Formation of Compounds $\left[\mathrm{A}_{1}-\mathrm{A}_{5}\right]$}

The compounds $\left[A_{1}-A_{5}\right]$ were also investigated at the lowest energy level with the Chem Draw Specialist 19.0 package (2019 version), as seen in figures (6-10). The heat of formulation of the prepared compounds $\left[A_{1}-\right.$ $A_{5}$ ] was also examined using the Chem3D 19.0 program, with positive heat formation for compounds $\left[A_{1}\right.$ and $\left.A_{3}\right]$, suggesting that the reactions of their preparation are endothermic, which is compatible with the functional findings. In comparison, the compound $\left[\mathrm{A}_{4}\right]$ had a negative formation temperature, meaning that their preparation reactions are exothermic, which contradicts the realistic findings. The compounds $\left[A_{2}, A_{5}\right]$ did not show the temperature of formation. As shown in table (7).

Table 4. Comparison between preparing compounds using the traditional method (reflux) and the microwave method

\begin{tabular}{|c|c|c|c|c|c|c|c|c|}
\hline \multirow{2}{*}{$\begin{array}{c}\text { Comp. } \\
\text { No. }\end{array}$} & \multicolumn{4}{|c|}{ Traditional method (reflux) } & \multicolumn{4}{c|}{ Microwave method } \\
\cline { 2 - 9 } & $\begin{array}{c}\text { T.Ref. } \\
\text { (hr.) }\end{array}$ & Yield(\%) & Solvent(ml) & Color & T.Ref.(min.) & Yield(\%) & Solvent(ml) & color \\
\hline $\mathrm{A}_{1}$ & 3 & 80 & 45 & Green & 4 & 90 & 15 & Green \\
\hline $\mathrm{A}_{2}$ & 3 & 55 & 45 & Red & 8 & 80 & 15 & Red \\
\hline $\mathrm{A}_{3}$ & 6 & 76 & 45 & Orange & 4 & 92 & 15 & Orange \\
\hline $\mathrm{A}_{4}$ & 7 & 43 & 45 & Yellow & 5 & 77 & 15 & Yellow \\
\hline $\mathrm{A}_{5}$ & 3 & 60 & 45 & Gray & 7 & 93 & 15 & Gray \\
\hline
\end{tabular}

Table 5. Antibacterial activity of the prepared compounds [A1-A5] and control antibiotic

\begin{tabular}{|l|l|l|l|l|l|l|l|l|l|l|l|l|}
\hline Comp. No. & \multicolumn{4}{l}{$\begin{array}{l}\text { E. Coil } \\
\text { Conc. mg/ml }\end{array}$} & \multicolumn{4}{l|}{$\begin{array}{l}\text { K. Pneumonia } \\
\text { Conc. mg/ml }\end{array}$} & \multicolumn{3}{l|}{$\begin{array}{l}\text { S. Aureus } \\
\text { Conc. mg/ml }\end{array}$} & \multicolumn{2}{l|}{$\begin{array}{l}\text { S. Epidermidis } \\
\text { Conc. mg/ml }\end{array}$} \\
\cline { 2 - 15 } & $\mathbf{2 5}$ & $\mathbf{5 0}$ & $\mathbf{1 0 0}$ & $\mathbf{2 5}$ & $\mathbf{5 0}$ & $\mathbf{1 0 0}$ & $\mathbf{2 5}$ & $\mathbf{5 0}$ & $\mathbf{1 0 0}$ & $\mathbf{2 5}$ & $\mathbf{5 0}$ & $\mathbf{1 0 0}$ \\
\hline $\mathrm{A}_{1}$ & 1 & 2 & 5 & 1 & 2 & 3 & 0 & 1 & 3 & 1 & 3 & 4 \\
\hline $\mathrm{A}_{2}$ & 0 & 1 & 3 & 1 & 2 & 4 & 1 & 2 & 2 & 1 & 3 & 4 \\
\hline
\end{tabular}




\begin{tabular}{|l|l|l|l|l|l|l|l|l|l|l|l|l|}
\hline $\mathrm{A}_{3}$ & 2 & 3 & 4 & 1 & 3 & 4 & 1 & 3 & 5 & 2 & 4 & 5 \\
\hline $\mathrm{A}_{4}$ & 2 & 3 & 5 & 2 & 3 & 4 & 2 & 2 & 4 & 2 & 3 & 5 \\
\hline $\mathrm{A}_{5}$ & 2 & 4 & 5 & 2 & 3 & 5 & 2 & 3 & 5 & 2 & 3 & 5 \\
\hline Amoxicillin & 2 & 3 & 4 & 2 & 4 & 4 & 2 & 3 & 4 & 1 & 2 & 3 \\
\hline Ampicillin & 2 & 4 & 4 & 2 & 3 & 3 & 2 & 3 & 4 & 2 & 2 & 3 \\
\hline Ciprofloxacin & 2 & 3 & 3 & 2 & 2 & 4 & 1 & 2 & 3 & 1 & 3 & 4 \\
\hline Blank disk & 0 & 0 & 0 & 0 & 0 & 0 & 0 & 0 & 0 & 0 & 0 & 0 \\
\hline
\end{tabular}

Table 6. The results of the irradiation of the prepared compounds [A1-A5] by laser beams

\begin{tabular}{|c|c|c|c|c|c|c|}
\hline \multirow{2}{*}{$\begin{array}{c}\text { Comp. } \\
\text { No. }\end{array}$} & \multicolumn{2}{|c|}{$10 \mathrm{~S}$} & \multicolumn{2}{c|}{ 20 S } & \multicolumn{2}{c|}{$30 \mathrm{~S}$} \\
\cline { 2 - 7 } & M.P. ${ }^{0} \mathrm{C}$ & Color & M.P. ${ }^{\circ} \mathrm{C}$ & Color & M.P. ${ }^{0} \mathrm{C}$ & Color \\
\hline $\mathrm{A}_{1}$ & $250-252$ & Green & $250-252$ & Green & $250-252$ & Green \\
\hline $\mathrm{A}_{2}$ & $210-212$ & Red & $210-212$ & Red & $210-212$ & Red \\
\hline $\mathrm{A}_{3}$ & $291-292$ & Orange & $291-292$ & Orange & $291-292$ & Orange \\
\hline $\mathrm{A}_{4}$ & $270-271$ & Yellow & $270-271$ & Yellow & $270-271$ & Yellow \\
\hline $\mathrm{A}_{5}$ & $258-260$ & Dark gray & $258-260$ & Dark gray & $258-260$ & Dark gray \\
\hline
\end{tabular}

Table 7. Heat of formation $\mathrm{Kcal} / \mathrm{mol}$ of synthesized compounds [A1-A5]

\begin{tabular}{|c|c|}
\hline Comp. No. & Heat of Formation $\mathbf{K J} / \mathbf{m o l}$ \\
\hline $\mathbf{A}_{1}$ & 189.51 \\
\hline $\mathbf{A}_{2}$ & ---- \\
\hline $\mathbf{A}_{3}$ & 403.23 \\
\hline $\mathbf{A}_{4}$ & -165.11 \\
\hline $\mathbf{A}_{5}$ & ---- \\
\hline
\end{tabular}

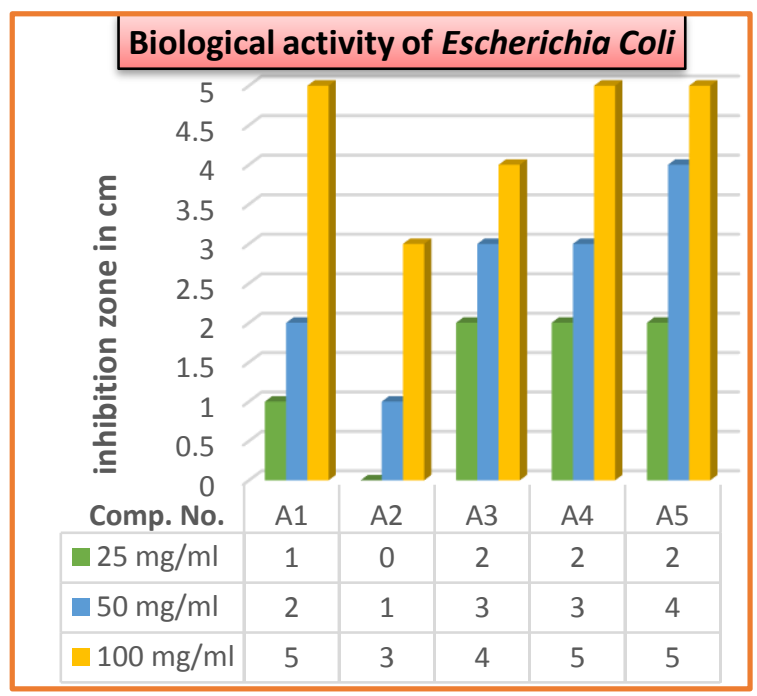

Scheme 2. Evaluation of inhibitory activity of $\left[A_{1}-A_{5}\right]$ for $E$. Coli

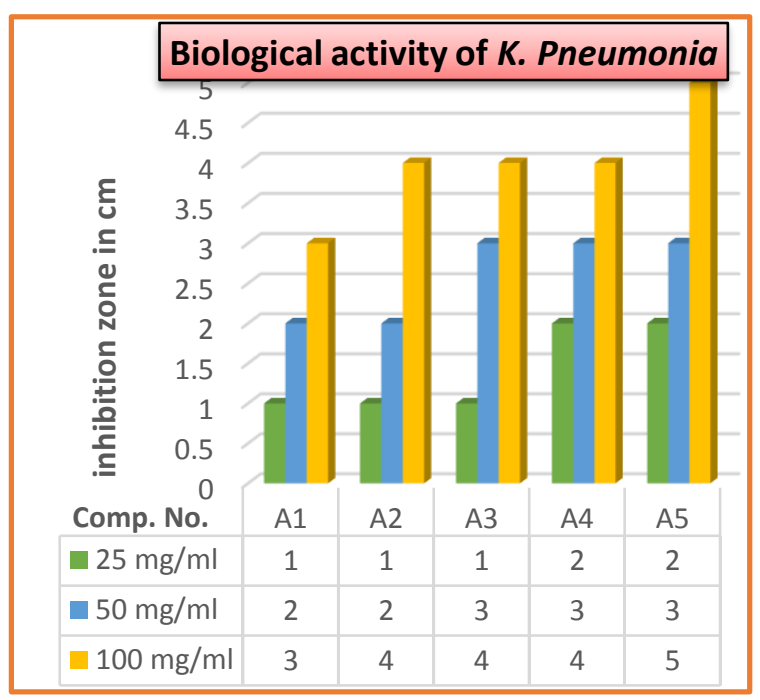

Scheme 3. Evaluation of inhibitory activity of $\left[A_{1}-A_{5}\right]$ for $K$. Pneumonia 


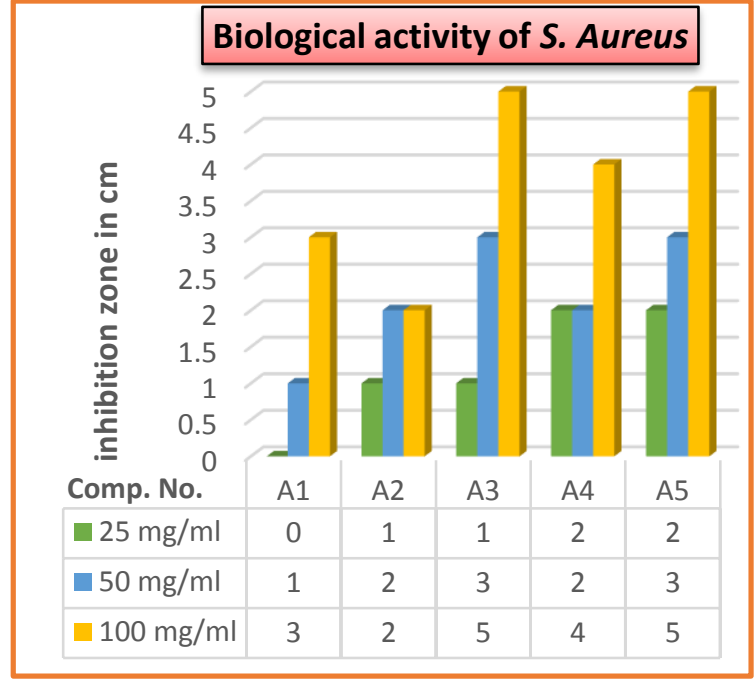

Scheme 4. Evaluation of inhibitory activity of $\left[A_{1}-A_{5}\right]$ for $S$. Aureus

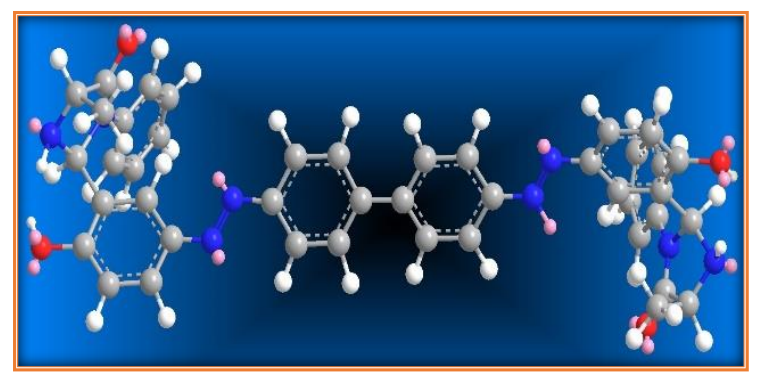

Figure 6. Stereochemistry of $\left[A_{1}\right]$

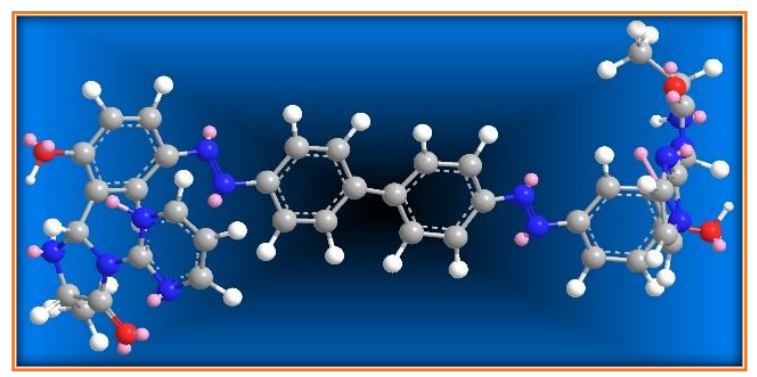

Figure 8. Stereochemistry of $\left[A_{3}\right]$

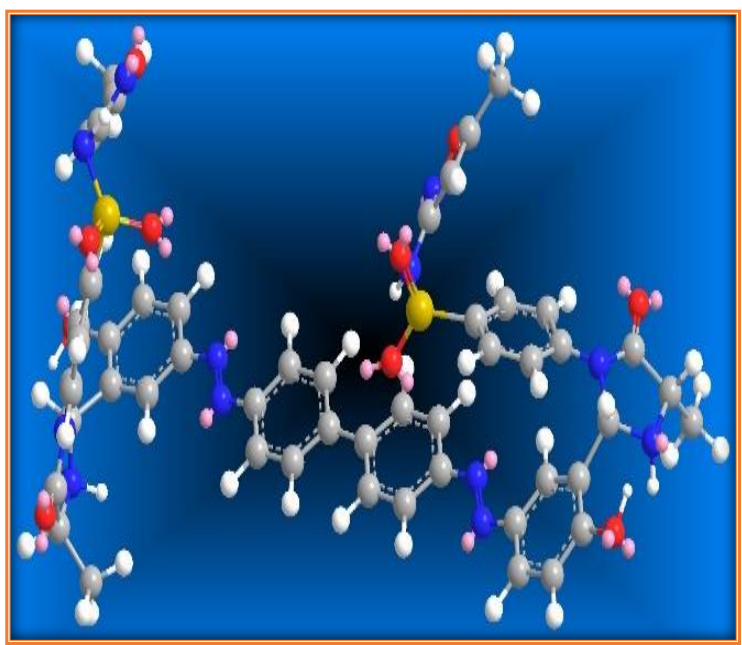

Figure 10. Stereochemistry of $\left[A_{3}\right]$

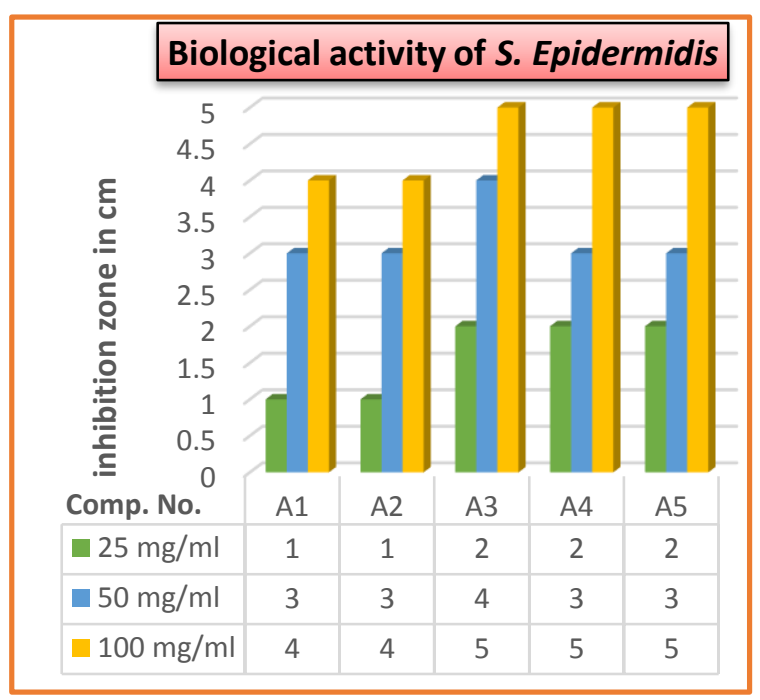

Scheme 5. Evaluation of inhibitory activity of $\left[A_{1}-A_{5}\right]$ for $S$. Epidermidis

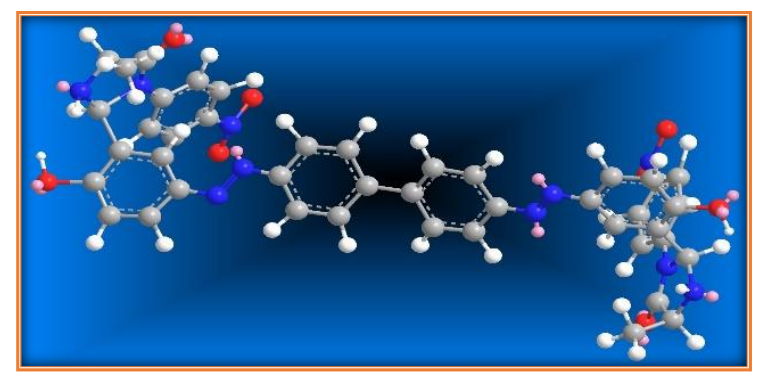

Figure 7. Stereochemistry of $\left[A_{2}\right]$

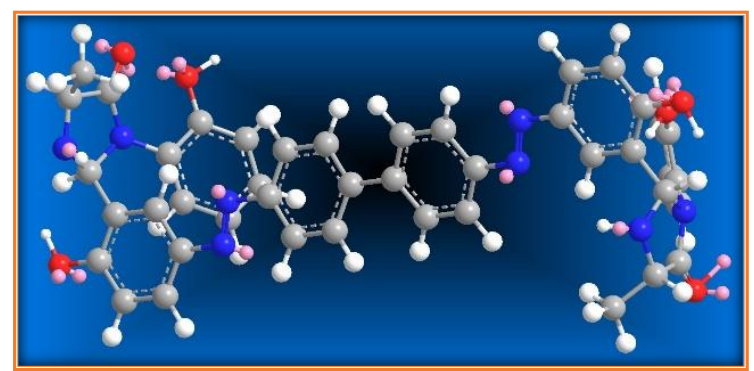

Figure 9. Stereochemistry of $\left[A_{4}\right]$

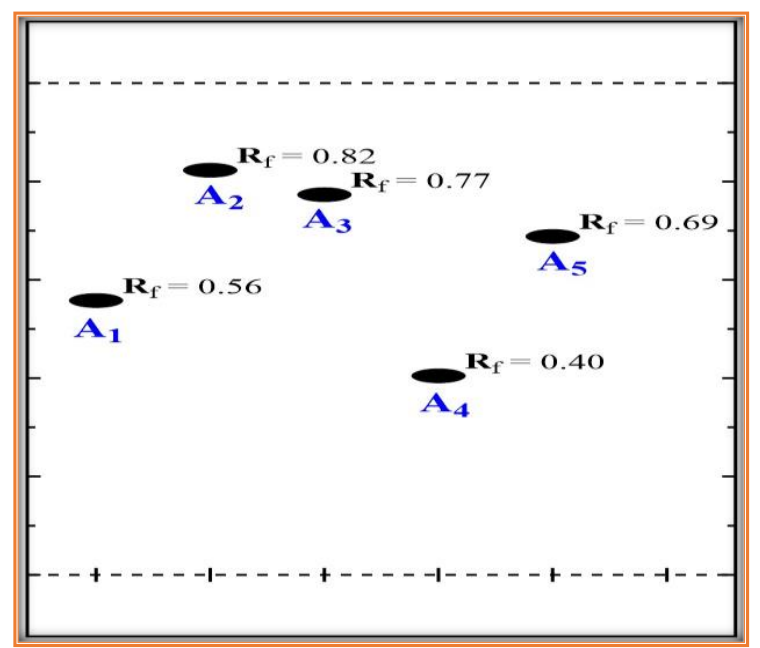

Figure 11. TLC spots and $R_{f}$ of $\left[A_{1}-A_{5}\right]$ 


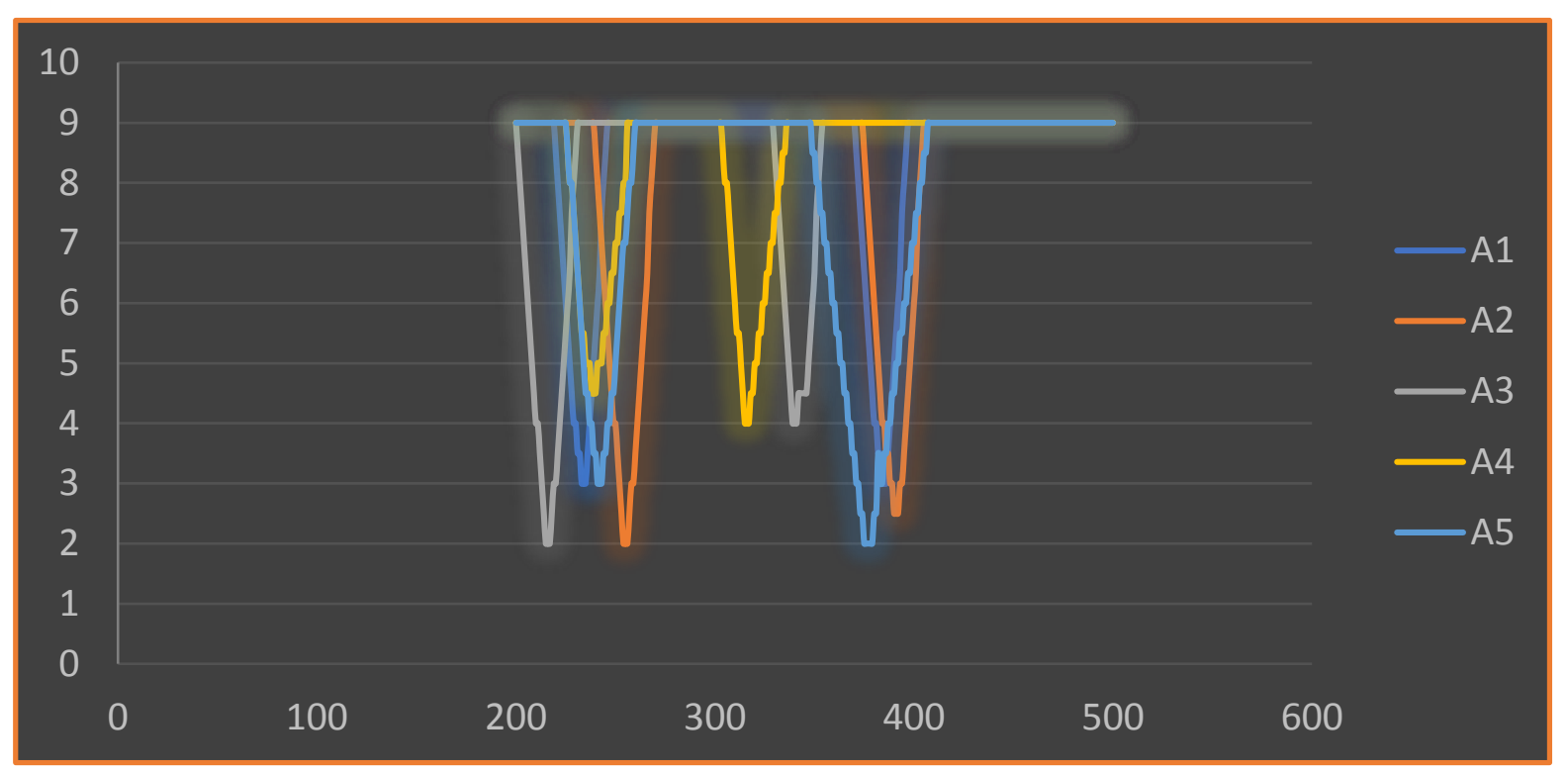

Figure 12. Uv-Viss. spectrum of compound $\left[A_{1}-A_{5}\right]$

\section{Conclusions}

The precision of the substances prepared is shown by spectroscopic measurements. It was found that using the microwave method gives better results than the traditional method (reflux) in terms of less time, higher productivity, and no catalyst. The prepared compounds $\left[A_{1}-A_{5}\right]$ also showed good solubility in many solvents. Compound $\left[A_{1}\right.$ and $\left.A_{2}\right]$ showed weak and moderate activity against the bacterial species used. Compounds $\left[A_{3}, A_{4}\right.$ and $\left.A_{5}\right]$ gave strong efficacy and high inhibition, reaching (5) $\mathrm{cm}$ at a concentration of (100) $\mathrm{mg} / \mathrm{ml}$ and reached (4) $\mathrm{cm}$ at Concentration (50) $\mathrm{mg} / \mathrm{ml}$ against all bacterial species used in the study. At the lowest energy stage, the stereoisomers and heat of creating the prepared compounds $\left[A_{1}-A_{5}\right]$ were also investigated. Positive heat formation was found in the Imidazolidin-4-one derivatives, suggesting that their preparation reactions are endothermic. The laser was used to irradiate the compounds $\left[A_{1}-A_{5}\right]$ for $(10,20,30)$ seconds. The substances were discovered to be untouched. When the melting point and color were determined, they did not disintegrate or polymerize. This indicates that the imports were unaffected by the laser beams. And they are dependable. The prepared compounds' thermal efficiency and optical stability were examined, and the findings revealed that they were stable.

\section{References}

[1] H. Zhao, Z.R. Qu, H.Y. Ye, R.G. Xiong, In situ hydrothermal synthesis of Imidazolidin-4-one coordination polymers with interesting physical properties, Chemical Society Reviews, 37(1) (2008) 84-100. [DOI]

[2] R.S. Upadhayaya, S. Jain, N. Sinha, N. Kishore, R. Chandra, S.K. Arora, Synthesis of novel substituted Imidazolidin-4-ones having antifungal activity, European journal of medicinal chemistry, 39(7) (2004) 579-592. [DOI]

[3] S.D. Khalaf, N.A.A.S. Ahmed, A.H. Dalaf, Synthesis, characterization and biological evaluation (antifungal and antibacterial) of new derivatives of indole, benzotriazole and thioacetyl chloride, Materials Today: Proceedings, (2021). [DOI]

[4] Aftan, M. M., Toma, M. A., Dalaf, A. H., Abdullah, E. Q., \& Salih, H. K. Synthesis and Characterization of New Azo Dyes Based on Thiazole and Assess the Biological and Laser Efficacy for Them and Study their Dyeing Application, Egyptian Journal of Chemistry, 64(5) (2021) 2903-2911. [DOI]

[5] V.H. Bhaskar, P.B. Mohite, Synthesis, characterization and evaluation of anticancer activity of some Imidazolidin-4-one derivatives, $\mathrm{J}$ Journal of Optoelectronics and Biomedical Materials, 2(4) (2010) 249-259.

[6] O. García Mancheño, C. Bolm, Synthesis of N(1 H)-Imidazolidin-4-one sulfoximines, Organic letters, 9(15) (2007) 2951-2954. [DOI]

[7] P.B. Palde, T.F. Jamison, Safe and efficient Imidazolidin-4-one synthesis in a continuous- 
flow microreactor, Angewandte Chemie, 123(15) (2011) 3587-3590.

[8] C.N.S.S.P. Kumar, D.K. Parida, A. Santhoshi, A.K. Kota, B. Sridhar, V.J. Rao, Synthesis and biological evaluation of Imidazolidin-4-one containing compounds as possible anticancer agents. MedChemComm, 2(6) (2011) 486-492. [DOl]

[9] K.L., Yu, R.L. Johnson, Synthesis and chemical properties of Imidazolidin-4-one peptide analogs. The Journal of Organic Chemistry, 52(10) (1987) 2051-2059.

[10] S.J. Wittenberger, Recent developments in Imidazolidin-4-one chemistry. A review, Organic Preparations and Procedures International, 26(5) (1994) 499-531. [DOI]

[11] I.Q. Abd, H. Ibrahim, H.M., Jirjes, A.H. Dalaf, Synthesis and Identification of new compounds have Antioxidant activity Beta-carotene, from Natural Auxin Phenyl Acetic Acid, Research Journal of Pharmacy and Technology, 13(1) (2020) 40-46. [DOI]

[12] I.A. Yass, M.M. Aftan, A.H. Dalaf, F.H. Jumaa, Synthesis and Identification of New Derivatives of Bis-1,3-Oxazepene and 1,3-Diazepine and Assess the Biological and Laser Efficacy for Them. The Second International \& The Fourth Scientific Conference of College of Science Tikrit University, (P4) (2020) 77-87.

[13] R.H. Saleh, W.M. Rashid, A.H. Dalaf, K.A. AlBadrany, O.A. Mohammed, Synthesis of Some New Thiazolidinone Compounds Derived from Schiff Bases Compounds and Evaluation of Their Laser and Biological Efficacy. Ann Trop \& Public Health, 23(7) (2020) 1012-1031.

[14] A.H. Dalaf, F.H. Jumaa, S.A.S. Jabbar, Synthesis and Characterization of some 2, 3dihydroquinozoline and evaluation of their biological activity, Tikrit Journal of Pure Science, 23(8) (2018) 66-67.

[15] S.M. Joshi, R.B. Mane, K.R. Pulagam, V. Gomez-Vallejo, J. Llop, C. Rode, The microwave-assisted synthesis of 5-substituted 1 H-Imidazolidin-4-ones via [3+2] cycloaddition over a heterogeneous Cu-based catalyst: application to the preparation of $13 \mathrm{~N}$-labelled Imidazolidin-4-ones, New Journal of Chemistry, 41(16): (2017) 8084-8091.

[16] A.J. Salwa, L.H. Ali, H.D. Adil, S.A. Hossam, Synthesis and Characterization of Azetidine and Oxazepine Compounds Using Ethyl-4-((4-
Bromo Benzylidene) Amino) Benzoate as Precursor and Evalution of Their Biological Activity, Journal of Education and Scientific Studies, 16(5) (2020) 39-52.

[17] M.M. Aftan, M.Q. Jabbar, A.H. Dalaf, H.K. Salih, Application of biological activity of oxazepine and 2-azetidinone compounds and study of their liquid crystalline behavior, Materials Today: Proceedings, 43 (2021) 2040-2050. [DOI]

[18] A.H. Dalaf, F.H. Jumaa, Synthesis, Identification and Assess the Biological and Laser Efficacy of New Compounds of Azetidine Derived from Benzidine, Muthanna Journal of Pure Science (MJPS), 7(2) (2020) 12-25.

[19] M.M. Aftan, A.A. Talloh, A.H. Dalaf, H.K. Salih, Impact para position on rho value and rate constant and study of liquid crystalline behavior of azo compounds, Materials Today: Proceedings, 45 (2021) 5529-5534. [DOl]

[20] T.J. Matos-Rocha, M.D.C.A.D. Lima, A.L.D. Silva, J.F.D. Oliveira, A.L.A. Gouveia, V.B.R.D. Silva, A.S.A.D.A. Júnior, F.A. Brayner, P.R.G. Cardoso, M.D.R. Pitta-Galdino, I.D. Rocha Pitta, M.J. Barreto de Melo Rêgo, L.C. Alves, M.G.D Rocha Pitta, Synthesis and biological evaluation of novel imidazolidine derivatives as candidates to schistosomicidal agents, Revista do Instituto de Medicina Tropical de São Paulo, 59 (2017).

[21] R.M.U. Mahmood, R.A.A. Ghafil, Synthesis and Characterization some Imidazolidine Derivatives and Study the Biological Activity, Annals of the Romanian Society for Cell Biology, 25(3) (2021) 569-584.

[22] E. Shobhana, R. Kesavasamy, H. Arul, R. Thirumurugan, B. Babu, Synthesis, structural, hirshfeld, spectral, thermal, Z-scan analysis and computational studies of 4-chloroanilinium quinoline-2-carboxylate (4CQ), Journal of Molecular Structure, 1204 (2020) 127516. [DOI]

[23] D. Kumar, J. Pandey, P. Kumar, V. Raj, Psyllium Mucilage and Its Use in Pharmaceutical Field: An Overview, Current Synthetic and Systems Biology, 5(1) (2017) 1-7.

[24] B.D. Salih, A.H. Dalaf, M.A. Alheety, W.M. Rashed, I.Q. Abdullah, Biological activity and laser efficacy of new Co (II), Ni (II), Cu (II), Mn (II) and Zn (II) complexes with phthalic anhydride. Materials Today: Proceedings, 43 (2021) 869-874. [DOl] 


\section{Funding}

No funding was received for conducting this study.

\section{Conflict of interest}

The authors have no conflicts of interest to declare that they are relevant to the content of this article.

\section{About the License}

(C) The author(s) 2021. The text of this article is open access and licensed under a Creative Commons Attribution 4.0 International License 